\title{
The Impact of the Treaty of Trianon on Hungarian Infrastructure
}

\section{Gergely Péterffy ${ }^{1}$}

\begin{abstract}
This study aims to give an overview of the clauses of the Treaty of Trianon specifically targeted at the Hungarian system of transportation, and its overall impact on the country's infrastructure. In the place of well-publicized slogans of "national self-determination," economic and strategic considerations were primarily at play in this issue, with the system of transportation at their intersection. Since railways represented the most important means of transportation at that time, given the fact that train connections were fast, cheap, and had a huge transport capacity, railroads came to the forefront of the postwar border settlement second only to natural or ethnic boundaries that could serve as bulwarks of the new borders. As it is commonly known, new borders created new divisions, cutting through traditional economic units, detaching major cities from their hinterlands. It is less well known what the repercussions were of the maimed transportation infrastructure on the national and regional levels.
\end{abstract}

Keywords: Hungary, infrastructure, railways, transportation, Treaty of Trianon, WWI

\section{Introduction}

New state boundaries were drawn at the end of the First World War. What was initially national upheaval in the name of "national self-determination" and enthusiasm for an independent national home to many, soon transformed into a race for territory to be ceded from countries that lost the war. So this happened in the case of the Dual Monarchy, too.

\footnotetext{
${ }^{1}$ Archivist at the Hungarian National Archives (Magyar Nemzeti Levéltár, MNL), PhD aspirant at Eszterházy Károly University of Eger. His research has been supported by the grant EFOP-3.6.1-16-201600001 "Complex improvement of research capacities and services at Eszterházy Károly University."
} 
doi: 10.14267/cojourn.2019v4n2a4

Due to revolutions, ${ }^{2}$ a popular upheaval establishing a weak republic, and a Communist 'palace coup', Hungary signed the peace treaty only on June 4, 1920. It reduced the country's territory to its third, and its population to 43 percent. The loss of homogenous Hungarian blocs, often along the Hungarian border, was pronouncedly painful. For practically everyone in Hungary, this signaled the greed of the 'successor states' (i.e. new states formed from the territory of the Dual Monarchy), and demonstrated the unreasonable nature of the postwar settlement. A vast majority of contemporaries, ${ }^{3}$ and even the later generations have not realized that the new borders taking shape during the spring of 1919 were in fact truly logical developments - seen from the angle of the neighboring countries.

The plans for postwar Europe, arising one after the other during the war, of the Entente - especially France - understandably focused on the weakening of Germany and on keeping it in check for the future. As for the Dual Monarchy, the solution in the eyes of the West European Allies was basically to keep Austria-Hungary intact but won over to the side of the Entente, thus effectively cornering Germany in a pincer move, and to preclude any possibility of a Mitteleuropa-type Central European integration. After the peace overtures of Charles IV of Hungary (Karl I in Austria), the memorable Sixtus Letters, went awry, the Hungarian king (and Austrian emperor) had to restrengthen his loyalty to the German emperor Wilhelm II on May 12, 1918, under humiliating provisions. This development made it obvious to London and Paris that the AustroHungarian state is subservient to the German Reich not only in the economic and military fields, but also politically. A new concept had to be developed. This alternative became the alliance of newly established states - carved out from the Slav-populated regions of Germany and the Monarchy - later to be joined by an enlarged Romania. The Little Entente (this apt term was coined by the Hungarian press some time in 1921) had a dual

\footnotetext{
${ }^{2}$ The so-called Aster Revolution, from 28 to 31 October, ousted the old elite of the Kingdom of Hungary from power, installing a democratically inclined republic instead. Due to increasing pressure from the Entente as well as the destituteness of postwar conditions, President count Mihály Károlyi was couped on 21 March. Political prisoners, including Communist, were released from prison, and on that day they took power in the country to establish a Hungarian Soviet Republic according to the Russian model. It lasted until August 1, 1919 when Romanian forces entered the Hungarian capital.

3 "Railway experts, responsible for contemporary transportation policies, simply did not get why had the Entente defined the borders of Hungary at the Paris Peace Conference in such a way as it did, marking lines on the map, without giving regard to any possible interest of the Hungarian State Railways (Magyar Államvasutak), ignoring all the rational economic and railway technical arguments of the railway management" (Eperjesi, 1992: 152).
} 
doi: 10.14267/cojourn.2019v4n2a4

task: to threaten Germany from the East, and to separate Soviet-Russia from Europe. ${ }^{4}$ French diplomacy had sketched plans for establishing smaller allied states in the wake of the division of the Habsburg Empire already in late-1917, after the scandal over the Sixtus Letters broke (Romsics 2007: 87). In order to make this plan feasible, the strengthening of the successor states became a must, thus replacing the principles of "national selfdetermination" with those of an economic strategy related to delineating the prospective new borders. Nevertheless, if the maximum of demands emanating from these considerations and the interests of the newly established states would have been met without restriction, the new borders of Hungary would have run along the lines of Ferto", Győr, Budapest, Jászberény, Szolnok, Pusztaszer, Baja, Kaposvár, Nagykanizsa, Zalaegerszeg and Szombathely (Suba, 1999: 17).

The weak point of the plan was implementation. Poland, now liberated from under the imperial rule and partition that lasted over one-hundred years, was surrounded by Germany and Russia, its two historical archenemies. The multiethnic Czechoslovakia, due to its Hungarian minority issue, could not concentrate exclusively on Germany; and likewise, the multiethnic Yugoslavia had to divide its focus between Hungary and Italy, alongside having a degree of tension with its ally, Romania, over the fertile Banat region, as well. ${ }^{5}$ Czechoslovakia and Yugoslavia were also affected by the aspirations of their own 'titulary' nationalities. The Croats expressed their disappointment already in the early 1920s with their new country, dominated by the Serbs, while a Slovak disenchantment with the Prague-based elite of Czechoslovakia took shape somewhat later. Both national movements lent support for the destruction of their respective compound countries at the earliest convencience. Romania absorbed many minorities with its conquests after the war, although their overall proportion was not as high as that of the minority or lesser nationalities in the previously mentioned Slavic countries. Still, the Hungarian, Bulgarian, and Soviet-Russian neighbors were glowing with vengefulness - something they could finally release in the early 1940s.

Thus, when on May 8, 1919, in Paris, the English, French, and Italian delegations - without regard to the perspective of those on the losing side - drew the new borderlines

\footnotetext{
4 The concept was a 'sanitary cordon' (Fr. cordon sanitaire) to isolate Soviet-Russia lest the Soviet 'virus' infect other European countries. It was a common term for the chain of countries from the Baltics through Poland, Czechoslovakia, and Romania.

${ }^{5}$ A major region of the historic Kingdom of Hungary divided into three by the Treaty of Trianon: today its western parts lay in Romania, the eastern ones in Serbia, while a smaller northern portion remained in Hungary.
} 
doi: 10.14267/cojourn.2019v4n2a4

in Central and Eastern Europe, they effectively sacrificed long-term stability on the altar of an overvalued alliance system (Palotás, 1990: 21). While the basis of this settlement was the principle of "national self-determination," there were economic considerations, represented by resources, industrial centers and transportation capacities, and the issue of the fate of infrastructure in the territory of the Dual Monarchy connected to these. Furthermore, strategic considerations were also at play, given that the system of railways could always serve military deployment and facilitate inter-allied communication as well. These were the major reasons as to why even purely Hungarian territories were eventually ceded to the successor states.

\section{Railways and borders}

The bulk of Hungarian economic and transportation experts have not relized the connection between the new borders and the railways, even as the track of railways determined as much as $40 \%$ of the net length of the borderlines delineated by the Treaty of Trianon. The present study summarizes the reasons behind the delineation of the new tracks, drawing on the research of Zoltán Palotás (Palotás, 1990: 37-56), its impact on railway transportation based on the joint study of the post-WWII Department for the Preparation for Peace at the Hungarian Minsitry of Foreign Affairs and the Ministry of Transport, as well as the proposals and summaries made by the Directorate of the Hungarian State Railways during the first half of 1946.

\section{The boundary with Czechoslovakia}

Czechoslovakia's geographical features profoundly influenced the final shape of the Czechoslovak-Hungarian border. This country was essentially a compound of two parts: the former Czech province of the former Austrian half of the Habsburg Monarchy, and parts of Upper Hungary and Carpatho-Ruthenia of the Hungarian half. The wedge-shaped entity was narrowing from West to East along a longitudinal axis of some $1000 \mathrm{kms}$. The Carpathian mountain range reached the eastern part of the country, which was dotted with North-South-oriented valleys. In the north, East-West connection was only provided by the valleys of the rivers Vág (in Slovak: Váh) and Hernád (Hornád), while in the south, such corridors only existed in the linguistically Hungarian territories. The railway connection that ran through the country with a length of $1300 \mathrm{~km}$ began at Cheb in the west, on through Prague and Oderberg (Bohumín), reaching Kassa (Košice) and, in the far eastern part of the country, Körösmező (Yasinia). East of Kassa (Košice) there 
doi: 10.14267/cojourn.2019v4n2a4

remained only one track that led to Carpatho-Ruthenia; on top of that, the KassaSátraljaújhely-Csap (Chop)-Királyháza (Korolevo)-Körösmező (Yasinia) line provided a direct connection to Romania at Halmi (Halmeu). Although the Slovak state did not exist prior to the First World War, the province had historical precursors, and its Northern and Western boundaries were accepted on a nationality basis. Its southern border was lingering open-ended with its North-South-oriented valleys. Territories northeast of Losonc (Lučenec) and east of Kassa (Košice) would have been left without railway connection in the absence of a major East-West railroad running in the South. That is why the new boundaries had to be drawn running well within the territory of the Hungarian-language bloc, and with the connecting line along the Pozsony (Bratislava)Galánta (Galanta)-Vágsellye (Šala)-Tótmegyer (Palárikovo)-Léva (Levice) route connecting the western and eastern railway systems of the new country. The fertile lands of the Csallóköz (Žitný ostrov) were ceded to Slovakia so as to service its highland industries; although, in this instance, the Danube River as a legitimate 'natural boundary' came handy. From the mouth of the River Ipoly (Ipel') to the easternmost part of the country, the whole eastern section of the Hungarian-Czechoslovakian border was determined by this railway that is still running just a few kilometers north of the border. To the southern route of such vital importance to the newborn state, the North-South lines connected at the stations of Ipolyság (Ipolské Šiahy), Losonc (Lučenec), Fülek (Fil'akovo), and Feled (Feledince). "Both the Kassa-Csap (Chop)-Királyháza (Korolevo) and the Kassa (Košice)- Losonc (Lučenec) main lines were running to their end stations within territories with a Hungarian majority, just a few kilometers north of the Trianondesignated border. The boundary, running in parallel to the southern railway line, is undoubtedly an "economically, specifically infrastructurally, devised line" (Palotás, 1990: 47). It is not by accident that in the August 2, 1921 session of the HungarianCzechoslovak Boundary Commission, the Hungarian party requested another track, along Pozsony (Bratislava)-Nagyszombat (Trnava)-Zólyom (Zvolen)-Murány (Muráň)Rozsnyó (Rožňava)-Kassa (Košice)-Perecseny (Perechyn)-Huszt (Khust), as being more appropriate from the viewpoint of Hungarians. Prague rejected the idea without consideration. The same thing happened to the second proposition that Budapest made, on August 20, wherein it would have given up only on the Hungarian-speaking community to the east of Kassa (Košice). In order to substitute for the worthwhile track of Kassa (Košice)-Sátoraljaújhely-Csap (Chop), the Hungarian party proposed to build 
doi: 10.14267/cojourn.2019v4n2a4

a new line between Carpatho-Ruthenia and Western Slovakia on favorable terms, but the proposal was to no avail (Suba 1999: 18).

From an economic point of view, the most serious consequences - beyond the fact that railway junctures were themselves economic hubs and now became inaccessible for most of their hinterlands — were brought about by the loss of Kassa (Košice) and its surroundings, as well as the valley of the Rima River. The administrative, educational, and industrial significance of Kassa (Košice) may speak for itself. Less well-known is the fact that the cession of the Rima Valley forced a complete change of course on one of the flagships of pre-war Hungarian industry, the Rimamurány-Salgótarján Ironwork Co. Its iron ore mines were still operating but now fell on the other side of the border. Thus, additional costs were generated by customs and transportation using the services of the Czechoslovak State Railways. Furthermore, the steel produced at the smeltery of Ózd then had to travel $216 \mathrm{~km}$ instead of the earlier $70 \mathrm{~km}$, since the Bánréve-Losonc (Lučenec)-Fülek (Fil'akovo) line was awarded to Czechoslovakia (Ministry of Transport, 1946: 8-10). On a local level, Nógrád county can be cited as an example of the effects of separation: the Railway of the Ipoly (Ipel') Valley was segmented into three smaller sections, by which the immediate connection between the agricultural area of West Nógrád and the industrial zone of East Nógrád ceased to exist. Although there were, post1945, plans to restore this connection with a new line between Szécsény and Salgótarján, and another plan was conceived based on a prospective Ózd-Pétervására-Kisternye track, both of these proposals remained on paper.

Another repercussion of delineating the new boundaries with Czechoslovakia was Hungary's losing its most important Western connection: the principle railroad from Budapest to Vienna through Vác, Érsekújvár (Nové Zámky), and Pozsony (Bratislava), an all-the-way double-track railway. The other line on the right bank of the Danube, running through Komárom and Györ, had only become a principal railway following the Treaty of Trianon, out of necessity. For this decision, however, a second track needed to be constructed in 1926 between Györ and Hegyeshalom, as well as minor line corrections had to be made in the Vértes mountains, since those lines had originally been built with secondary-line parameters back in the late-1880s.

\section{The boundary with Romania}

The Bucharest elite first imagined a new Romanian boundary by the river Tisza, a proposition which the Entente did not wish to accommodate, party as "punishment" for 
doi: 10.14267/cojourn.2019v4n2a4

the separate peace with the Central Powers which Romania concluded in $1918 .{ }^{6}$ However, a vast territory as far west as the rimlands of the Great Hungarian Plains were ceded to Romania. With Transylvania, the parts of the Partium ${ }^{7}$ and the Banat, some $103000 \mathrm{~km}^{2}$ of territory, came under Romanian sovereignty, which was an altogether larger area than the one which remained under Hungarian control. With those territories, Transylvanian ore and salt, and vast forest regions, were ceded to Romania, as well as important industrial centers which earlier played a key role in the economy of the Habsburg Monarchy: Arad (Arad), Brassó (Brașov), Petrozsény (Petroșani), Resicabánya (Reșiţa), Temesvár (Timişoara), and Vajdahunyad (Hunedoara).

Due to the geographical features of the ceded territories, there are/were few transportation corridors between Transylvania and the Partium. For strategic and economic reasons, the Western boundaries of Romania could not spare the connectordistributor lines linking together these scarce corridors through a North-South axis, which, on top of that, connects to the Kassa-Csap (Chop)-Körösmezö (Yasinia) line as well. It is not by accident, then, that the new boundary was moulded to follow the Arad (Arad)-Nagyszalonta (Salonta)-Nagyvárad (Oradea)-Szatmárnémeti (Satu Mare)Királyháza (Korolevo) line, about 3 to $8 \mathrm{~km}$ away to the west. The transversal corridor connecting the so-called market towns has been nearly completed by 1914 - the phase between Kisjenö (Chișinău) and Nagyszalonta (Salonta) were later built by the Romanian rail company, while some sections with weaker structures were upgraded to principal-line level - the original aim, when these sections were built, was to provide for an alternative so that all East-West transport not go through the radial lanes converging in the Hungarian capital, to thus relieve Budapest. Prior to the war, it was the market places of Arad (Arad), Nagyszalonta (Salonta), Nagyvárad (Oradea), Nagykároly (Careie), Szatmárnémeti (Satu Mare) (as well as Beregszász [Beregove]) where the agricultural goods of the Great Plains could be exchanged for the raw materials of the mountain ranges. By ceding those cities, but not their hinderlands, the latter were left without their

\footnotetext{
${ }^{6}$ After the Treaty of Brest-Litovsk (March 3, 1918) Romania became isolated in the eastern theater of war. Due to the military advances of the Central Powers, Romania unilaterally sued for peace. By the Treaty of Bucharest (May 7, 1918), the country ceded most of Dobruja to Bulgaria, leased oil wells to the German Reich, and gave control of the mountain passes to Austria-Hungary, in return for the recognition of Romanian unity with Bessarabia.

${ }^{7}$ Hungarian region, formed during the Early Modern Period that geographically and culturally belonged to Hungary proper, while it was under the authority of the Principality of Transylvania. Its name Partium is derived from the Latin word pars (= a part), meaning that these territories were "parts of Hungary" adjoint to Transylvania. By the Treaty of Trianon, the Partium was divided with some $40 \%$ ceded to Romania, $20 \%$ remaining in Hungary, while another $20 \%$ was ceded to Czechoslovakia. This latter part was annexed by the Soviet Union during WWII and now forms part of Ukraine under the name Carpatho-Ukraine.
} 
doi: 10.14267/cojourn.2019v4n2a4

natural markets, and most of today's Szabolcs-Szatmár and Hajdú-Bihar counties were practically left without urban centres. In turn, with the mutilation of their agglomeration, these market towns, becoming part of Romania, have lost their primary trading functions, since they could not exchange the minerals and timber of the mountains for agricultural products from the Plains.

\section{The Boundaries with the Kingdom of Serbs, Croats, and Slovenes}

The basis of Serbian aspirations was the line along the river Dráva (Drava)-Pécs-BajaSzeged-river Maros (Mureș): partly to secure natural boundaries provided by the two rivers, partly to acquire hard coal mines in the Baranya region, partly to secure the inclusion of strategic transportation hubs like Szeged, Baja, and particulary the Danube bridge at Baja. While ethnic composition was obvious in Slavonia's case, the Slavic element amounted to a mere $20 \%$ in the Drávaszög (i.e. "Drava corner"), while the Bácska region was considered all-Hungarian as far as the Ferenc Channel (the Danube-TisaDanube Canal). The Drávaszög came under the authority of Belgrade due to military considerations, while Szabadka (Subotica) had to be ceded with a view to transportation.

It was not by chance that French and Serbian troops marched as far as this line in the final phase of WWI, since there were no railway bridges on the Danube south of Belgrade, and neither were there any on the Tisza south of Szeged. By this time, the only route to Romania went through Szeged: that is why it was only after the completion of the Tisza Bridge at Zenta (Senta) that occupation forces ${ }^{8}$ were withdrawn from Szeged. To do so, they had to make principal railways out of the secondary ones, and construct the missing phases, such as the one between Zenta (Senta) and Csóka (Čoka), spanning a distance of $10 \mathrm{kms}$, alongside the aforementioned bridge over the Tisza river. The famous Simplon-Orient Express was operating from Paris to Istanbul, getting around Hungary from the south, on the line of Paris-Milan-Trieste-Zagreb-Vinkovici(-Belgrade-NišIstanbul)-Szabadka (Subotica)-Zenta (Senta)-Nagykikinda (Kikinda)-Temesvár (Timișoara)-Orsova (Orșova)-Bucharest.

From a Hungarian perspective, by ceding Szabadka (Subotica), the route from Baja to Szeged was prolonged from $68 \mathrm{kms}$ to $150 \mathrm{kms}$ by adding a detour along

\footnotetext{
${ }^{8}$ Parts of Hungary were occupied since November 1919 but the use of force was specifically encouraged by the Entente in order to "stop the spread of Bolshevism." The Hungarian Soviet Republic, already under a lot of domestic and international stress, was already on the verge of collapse, but the short Romanian occupation of Budapest gave its coup de grace. Several days later, the Entente ordered the Romanian army to withdraw.
} 
doi: 10.14267/cojourn.2019v4n2a4

Kiskunfélegyháza-Kiskunhalas-Bácsalmás, which practically meant a $120 \%$ rise in journey length and a 70 to $75 \%$ rise in added transport costs. To a lesser extent and with lesser impact, the cession of Regöce (Riđica) had the same consequences. By awarding the juncture of vicinal railways to the Southern Slav state, the territories south of the BajaBácsalmás line lost their railway connection. With the cession of the Drávaszög region, townships along the Drava river had to pay more for transport, since they had to turn to the route from Pécs through Mohács to finally embark their agricultural products, for water transport - instead of simply using the Danube port at Kisköszeg (Batina).

The Romanian-Hungarian-Serbian boundary, on top of that, divided the Dombóvár-Baja-Békéscsaba-Nagyvárad (Oradea) transversal lane into three, the track which previously connected the Great Plains to the Danube-Tisza Interfluve and Transdanubia. Tranports from the Viharsarok region to the Baranya region thus depended on either the longer bypass to Budapest (on a prinicipal railway), or the somewhat shorter (but more time-consuming) bypass to Baja (Minsitry of Transport, 1946: 8-10).

\section{The boundary with Austria}

The boundary between Austria and Hungary is the only border drawn during the Paris Peace Conference in a way that may be described as sensitive to ethnographic realities only a population of cca. 10,000 Hungarians were assigned to the Republic of German Austria. From an infrastructure perspective, it was only the bisecting of the SopronKöszeg lane that caused some difficulties, as well as the minor Bük (Wichs)-Felsőlászló (Oberloisdorf) lane connecting to the former. Albeit at some extra cost and extra time, the principal line between Sopron and Szombathely could serve the needs of its broader environment - although Sopron, Szombathely, and Köszeg were hit hard by losing their western hinterlands.

\section{The impact of the Peace Treaty on the Hungarian transportation system}

The kingdom of Hungary lost two-thirds of its territory and $57 \%$ of its population. The country shrank from a territory of $282000 \mathrm{~km}^{2}$ to $93000 \mathrm{~km}^{2}$, but this area retained the bulk of its processing capacities, while the resources of mountains and forests went to the successor states (Romsics, 2004: 147). It was a unitary economic system that was divided: "With the division of Hungary, the unity of economies, traffic, river control, water management and forestry was over" (Czére, 2000: 58). 
doi: 10.14267/cojourn.2019v4n2a4

In terms of the national road network, the country faced serious losses, too: only $27,588 \mathrm{~km}$ of public roads ( $37 \%$ of the pre-war total) were left within Hungary's new confines, and, on top of that, there were only a few in the Great Plains which were able to service traffic during the heavy spring and autumn rainfalls. Due to the geographic features of the Carpathian Basin, and the previous infrastructure of the country, the number of bridges dropped by only $32 \%$. As for the number of registered passanger cars, by the end of 1919, there remained hardly any car in running order. During WWI, many passanger cars was confiscated by the army and were later destroyed or looted by enemy forces; another portion broke down due to tyre and fuel shortages. During the time of its reign, the Hungarian Soviet Republic could only confiscate a few cars and trucks from the civilian population. After the war and revolutions, not many vehicles were operational: in late-1918, the number of registered passanger cars was still 3174, while by 1920 a mere 1672 appeared in statistical data, although by this time, however small in numbers, vehicle imports began to expand (Frisnyák, 2001: 148, 157). Due to tyre shortages, some of the vehicles ran on iron rims. On October 13, 1920, the speed limit and area accessible by vehicles on iron rims have been reduced, but the use of tyres was only prescribed as late as in 1925 (Frisnyák, 2001: 163).

New boundaries naturally had an impact on the public road system as well, although the documents for the preparation of peace in 1946 only mentioned the public roads connecting to 2 or 3 villages that have become difficult to access, and the complaints of the villagers who consequently had to make large detours. By tearing natural agglomeration apart, new roads had to be constructed to make regional hubs available for those townships that have lost their previous connections. The longest such road was $121 \mathrm{~km}$ long, connecting Bátaszék, Baja and Szeged. Minor ones were constructed near Barcs and Debrecen. Altogether, as much as $173 \mathrm{kms}$ of new public roads were built due to the change of state borders.

As there was not enough money and labor allocated to the maintenance of railroads, the servicing of public roads was also in a state of gradual decay. While in 1913, for the maintenance of state roads, $42 \mathrm{~m}^{3}$ crush stone and gravel was used, this number shrank to $6 \mathrm{~m}^{3}$ and zero, respectively, by 1919. By 1924, only $50 \%$ of public roads was up to pre-war quality. Alongside the general economic environment, an additional factor behind this deterioriaton was the fact that important mines were ceded to other countries, and those remaining in the mountains of the Bakony, Börzsöny, Cserhát, and TokajZemplén mountains could not fully meet the demand of Hungary (MÁV, 1946: 74-94). 
doi: 10.14267/cojourn.2019v4n2a4

Railways were hit hardest: out of its 22,869 kms of network length, only 8,705 kms remained within the new confines of the country, and the most important junctures, as was demonstrated earlier, were ceded to the successor states. In the unitary economic zone of Austro-Hungarian Monarchy, there were only five customs toll stations in the direction of Romania and Serbia. Newly established boundaries, however, cut across 50 railways in open line, creating 42 new border stations, and the successor states were only willing to take over traffic at 22 locations. After 1920, Hungary had to broker separate economic and trade agreements with all of the four successor states. The hardships of railway transportation were exacerbated by the fact that the Romanian army looted twothirds of Hungarian engines, and four-fifths of carriages, and there was also a general shortage of coal, steel and oil (Czére, 2000: 57-62). Due to boundary delinations, the Fehérgyarmat-Zajta line was separated from the national network, and this region along the Szamos River was re-included only by early 1926.

Article 302 of the Treaty of Trianon gave the right to the Czechoslovak state railways to use the Hungarian phase of the Losonc (Lučenec)-Csata (Čata) line with their own vehicles and personnel for 15 years. The same beneficial treatement was due to the Romanian railways, for 10 years, for using the line connecting Nagyszalonta (Salonta)Békéscsaba-Arad (Arad)-Kisjenő (Chișinău). In Article 305, as a sort of compensation for the Czech-Serbian corridor that never came to be, Czechoslovakia got the right to transport, with its own vehicles and personnel, along the Pozsony (Bratislava)-SopronSzombathely-Murakeresztúr-Pragerhof-Fiume (Rijeka) and the Pozsony (Bratislava)Hegyeshalom-Csorna-Hegyfalu-Zalaszentiván-Murakeresztúr-Fiume (Rijeka) lines to the Adrian ports. In order to ensure operations, the Czechoslovak state also had the right to build maintenance facilities on Hungarian soil. On top of that, if the Czechs demanded it, the Hungarian state would have been obliged to renovate the Pozsony (Bratislava)Nagykanizsa line for the trains that were called vernacularly as "the corridor trains" (Eperjesi, 1992: 145).

Neighboring countries, in order to tighten their grip on Hungary and make economic recovery more difficult, wanted to exclude the country from international transportation of which one symbolic example was the redirection of the Orient Express from its original track. Instead of running through Vienna and Budapest, a Paris-MilanTrieste-Zagreb-Temesvár (Timișoara)-Bucharest track was assigned to the famous luxury railway until June 1, 1921, when it was re-directed back to its original line. Interstate economic, trade, and transportation solutions were, due to the reasons detailed 
doi: 10.14267/cojourn.2019v4n2a4

above, prolonged until the end of 1932. As to passanger traffic and the transportation of goods, the first immediate bilateral treaty was signed with Czechoslovakia on November 7, 1922. The last in the series of such agreements was with Romania on December 28, 1932 (Eperjesi, 1992: 176-178).

Successor states were often willing to undertake additional costs and travel duration due to detours so as not to let Hungary reap high transit profits. Due to traffic detour, the yearly 1.5 million tons of transit traffic registered by MÁV (Hungarian State Railways) dropped to 300,000 tons, and in spite of all the pricing efforts and international agreements, it could not surpass 850,000 tons by 1938 . This was, of course, a serious loss of profits for the country's economy. The three members of the Little Entente could transport through the Orsova (Orşova)-Temesvár (Timișoara)-Arad (Arad)-Nagyvárad (Oradea)-Szatmárnémeti (Satu Mare)-Halmi (Halmeu) line - although this meant a lengthy detour. Through the territory of Hungary, the distance between Brno and Arad was only $609 \mathrm{~km}$. The distance to be covered grew to $1024 \mathrm{kms}$ via Kassa (Košice) and Királyháza (Korolevo), when circumventing Hungarian territory. Similar disadvantages applied to travelling from Vienna to Belgrade (913 kms instead of $614 \mathrm{kms})$ or from Zagreb to Kassa (Košice) (1002 kms instead of $646 \mathrm{kms}$ ) when taking a circumventing detour (MÁV, 1946: 11-27).

It is worth mentioning how the successor states maintained the railway system in the interwar period. The best performance was that of the Czechoslovak State Railways who replaced the older tracks on a length of $695 \mathrm{kms}$ between 1919 and 1938. They modernized not only the strategically important East-West lanes but also the offsetting minor ones. New trackways were only laid at the Kassa (Košice) station in 4 kms length for the subordinate yard, and a 3-kilometre delta track at Sajólénártfalva (Lenartovce) so as to be able to bypass Bánréve on Hungarian soil, when travelling from Kassa (Košice) to Fülek (Fil'akovo). According to the assessment of the Hungarian State Railways (MÁV), in the 20-year period in question, the Czechoslovak state proportionally invested as much into the railway system of former Upper Hungary as did MÁV for its own railways in the same period.

On the other hand, Romanian State Railways only replaced $468 \mathrm{kms}$ of tracks between 1919 to 1940 . Only $90 \mathrm{kms}$ of new lanes and tracks were built, and these mostly 
doi: 10.14267/cojourn.2019v4n2a4

out of strategic considerations. Expressed in 1938 terms, a total of 110 million pengó ${ }^{\prime \prime}$ was spent on the development of the railway system of Transylvania.

The South Slav state only modernized the line between Szabadka (Subotica) and Újvidék (Novi Sad) and the one between Szabadka (Subotica) and Zenta (Senta) between 1919 and 1941, amounted to $82 \mathrm{kms}$ covered. Only as little as 4 million pengö worth was invested in the railway systems of the Bácska and Bánát regions, which - given the high density of the network there - was practically insignificant (Vasúti kérdések, 1946).

A common myth needs to be addressed with regard to the effects of the peace treaty. This false thesis was first published in the work of Béla Unyi, in his Transformation of our Railway System from 1914 to our Times (Vasúthálózatunk alakulása 1914-től napjainkig), according to which certain doube-track lanes - namely, the Hatvan-Salgótarján, Békéscsaba-Lökösháza, and Budapeset-Kunszentmiklós-Tass lanes - had to be removed at the insistence of the Little Entente powers so as to evade a possible Hungarian mobilization along those lines (Unyi, 1989: 10). ${ }^{10}$ There was no such clause in the Treaty of Trianon, no documents were found which would support this finding, and neither daily papers nor the Railway and Transportation Gazette (Vasúti és Közlekedési Közlöny) took notice of track removal for military reasons, as suggested in the above-quoted piece of work. The Hatvan-Salgótarján lane operated on a double-track until its destruction in WWII. Along the way to Belgrad, a second track was indeed built from Budapest to Kunszentmiklós-Tass by the summer of 1918 (Keller, 1992: 354), although the lost war and the new borders delineated by the peace treaty made it unnecessary to use or build second tracks there. The traffic, scarce as it was due to coal and vehicle shortages, could be operated on single-tracks just as well on the much more frequented principal railways. Removal of tracks, where it indeed took place, was rather a consequence of the desperate shortage of material. During war times, the enormous traffic and the relatively low level of maintenance left the lanes in dangerous conditions. The economic position of the country did not make it feasible to procure enough steel, and constructors needed to obtain the necessary material by removing existing, lesser tracks to maintain traffic along the critical sections of the system (about material procurement practices of MÁV, see Kelety, 1921: 200-203).

\footnotetext{
${ }^{9}$ Hungarian currency at the time, used between 1927 and 1946.

${ }^{10}$ The theory is further contradicted by the fact that the double-track principal railway of BudapestMiskolc-Sátoraljaújhely is not included, in spite of being a principal route reaching as far as the state boundary, at a place as strategically distant from Prague as Kassa (Košice).
} 
doi: 10.14267/cojourn.2019v4n2a4

As for waterways, the immediate domestic connection between the Danube and the Tisza ceased to exist, as the Francis Channel was ceded to the South Slav sate. The Hungarian section of the Danube was shortened from $927 \mathrm{kms}$ to $417 \mathrm{kms}$, while that of Tisza's from 680 to 462. Domestic waterways had a net total length of $4971 \mathrm{kms}$ in 1918 of which only as much as $3072 \mathrm{kms}$ was navigable by steamers, i.e. suitable for significant freight traffic. Not only ports, but the construction docks of Orsova (Orşova) and Komárom (Komarno) were also lost. As much as 30\% of motor boats and $50 \%$ of track boats were inherited by the successor states.

With the loss of Fiume, immediate access to the sea was lost for Hungary, which in turn made overseas export-import activities much more expensive. Transportation costs relating to the use of the Romanian and Yugoslavian railways connecting to the Adrian and Black Seas were significant. The situation was - somewhat - alleviated with the introduction of seafarer cargo boats on the Danube - the first of which was the Budapest - through which the Levant could be reached without intermediaries.

Civil aviation, both passanger and cargo, both of which were only in the making on national and international levels, was not limited by the Treaty of Trianon. Aviation in the early 20th century developed at an enormous pace, but its level of technical development did not at the time make it a major means of transport yet.

\section{Conclusion}

Summing up the impact of Trianon on Hungarian transportation, it is easy to demonstrate that the new boundaries were, and continue to be, serious impediments to the life of Hungary. Although missing public roads were easier to replace, the replacement of many missing railway junctures, due to financial, and partly also political, reasons, is yet to be implemented. In recent years, there appeared news about reconnecting torn railway connections in the framework of regional cooperation, such as the Ipolyság railroad or the plans for Szeged-Szabadka (Subotica), a realisation of these projects cannot be expected in the near future due to the lack of serious political will and sound financial background.

\section{Works cited}

Czére, B (2000): Magyarország közlekedése a 20. században. [Hungary’s transportation in the 20th Century]. Budapest. Magyar Államvasutak. 
doi: 10.14267/cojourn.2019v4n2a4

Eperjesi, L (1992): Magyarország közlekedése a trianoni békeszerzödés után. A nemzetközi kapcsolatok alakulása 1920-1938 között. [Hungary’s Transportation after the Treaty of Trianon. International Relations from 1920 to 1938] In: Közlekedési Múzeum Évkönyve. [Yearbook of the Museum of Transportation] 1988-1992. Budapest. 141-180.

Frisnyák, Zs (2001) A magyarországi közlekedés krónikája (1750-2000). [Chronicle of Hungarian Transportation, 1750-2000]. Budapest. MTA TTI-História.

Kelety, D (1921): A megcsonkolt államvasutak. [Maimed State Railways] In.: A Magyar Mérnök és Építész Egylet Közlönye. [Bulletin of the Hungarian Enginerering and Architecture Association] 55. évf. 26. szám. 193-210.

MÁV (1946) Magyarország közlekedési problémái. [Problems of Hungarian Transportation] MNL OL. Z 1610. 485. d.

Közlekedésügyi Minisztérium (1946) [Ministry of Transport]: Magyarország közlekedési problémái a békekötéssel kapcsolatban. [Hungary's Transportation Problems with Regard to the Peace Treaty] MNL OL. M-KS. 274. f. 10. cs. 25. öe.

Palotás, Z (1990): A trianoni határok. [Boundaries of Trianon] Budapest. Interedition Romsics, I (2007): A trianoni békeszerződés. [The Treaty of Trianon] Budapest. Osiris Suba, J (1999): Magyarország határának kitüzése és felmérése 1921-1925 között. [Delineation and Survey of Hungary's Boundaries, 1921-1925] Doktori disszertáció. [PhD Thesis] Budapest.

Unyi B, (1989): Vasúthálózatunk alakulása 1914-töl napjainkig. [Transformation of our Railway System from 1914 to our Times] Budapest. KÖZDOK.

Vasúti kérdések (1946) [Railway Issues] Vasúti kérdések béketárgyalási előkészitő anyaga. [Railway Issues - Preparatory Document for the Peace Negotiatins] MNL OL Z 1610. 486. d. 